\title{
Pericardial Germ Cell Tumor
}

National Cancer Institute

\section{Source}

National Cancer Institute. Pericardial Germ Cell Tumor. NCI Thesaurus. Code C45761.

A rare benign or malignant germ cell tumor that arises from the pericardium. The reported cases have been teratomas and yolk sac tumors. 